Original Research Paper

\title{
Evaluation of Hybrids and Cultivars of Single type Tuberose (Polianthes tuberosa)
}

\author{
Jadhav S.B. *, Vichare S.V. and Katwate S.M. \\ Department of Horticulture, Mahatma Phule Krishi Vidyapeeth \\ Rahuri Dist. Ahmednagar - 413 722, Maharastra, India \\ Email : satishjadhav061321@gmail.com
}

\begin{abstract}
Hybrids and cultivars of single type tuberose was evaluated to fulfill the need to develop new hybrids as demanded by commercial growers. Evaluation of fifteen genotypes showed significant variation in growth, floral and bulb characters. Cultivar Arka Prajwal was significantly superior over all genotypes, which recorded least number of days for opening of $1^{\text {st }}$ floret $(78.55$ days) with maximum diameter of spike $(1.18 \mathrm{~cm})$, length of floret $(6.05$ $\mathrm{cm})$, weight of individual floret (3.12 g) and weight of spike (121.43 g).The hybrid genotype L1P4 (Variegated X Phule Rajani) was observed to be superior in terms of rachis length $(39.78 \mathrm{~cm})$, inter-nodal length $(7.25 \mathrm{~cm})$, length of bulb $(8.09 \mathrm{~cm})$, diameter of bulb $(3.76$ $\mathrm{cm})$ and diameter of bulb-lets $(1.85 \mathrm{~cm})$. Among the hybrid genotypes L1P4 also recorded maximum plant height $(116.39 \mathrm{~cm})$, spike length $(109.58 \mathrm{~cm})$, weight of cut spike $(105.08$ g) and vase life (11.00 days). However, it was foundto be at par for number of florets per spike (57.25), length of floret $(5.92 \mathrm{~cm})$ and number of spikes per clump (10.14) with all other cultivars and hybrids tested. From the overall performance, it was found that the cultivar Arka Prajwal was the best. Genotype L1P4 found promising for loose as well as cut flower production because of its number of florets, inter-nodal length and spikes per clump which are important characters considering loose flower for taking maximum number of pickings. However, characters such as rachis length, spike length, vase life and weight of spike which are imperative for cut flowers are also noted superior in genotype L1P4.
\end{abstract}

Key words: Bulb, Flower, Growth, Hybrid and Single type tuberose

\section{INTRODUCTION}

Tuberose (Polianthe stuberosa) is one of the most importantcut and loose flowers in India. It is anornamental bulbous plant, native to Mexico from where it has spread to different parts of the world during the $16^{\text {th }}$ century. It belongs to family Asperagaceae and is popularly known as 'Rajnigandha'(Yadav and Maity,1989). The nomenclature of different types of tuberose is based on the number of rows of petals each flower possesses. The cultivar with single row of petals is designated as 'Single' while the one which bears more than three rows of petals is called 'Double'. The cultivar 'Semi-Double' bears flowers with two-three rows of petals. Valuable natural aromatic oil is extracted from the flowers for the high cost perfume industry. The flower of single petalled cultivars reported to contain $0.08-0.135 \%$ concrete and yield $0.08-0.11 \%$ essential oil in India (Singh, 2006). The serene beauty of flower spikes, bright white flowers, sweetness of blooms and delicacy of fragrance of this ornamental crop transform the entire area into a nectarine and joyous. Varieties which perform well in one region may not do well in other locations due to varying climatic conditions. Hence, it is important to study morphological variation and performance of genotypes for important yield contributing characters. Hence, the present investigation was undertaken to evaluate the single type tuberose for growth, flower and bulb yield for Western Maharashtra.

\section{MATERIALS AND METHODS}

The present study was conducted at the National Agricultural Research Project Ganeshkhind, Pune7, MPKV; Rahuri, during 2014-2015. Geographically, Pune is situated at $18^{\circ} 32^{\prime}$ North latitude and $73^{\circ} 51^{\prime}$ East longitude on Deccan plateau at the confluence of Mula and Mutha rivers. The controlled hybridization programme 
using available cultivar of single type of tuberose is already in progress at All India Co-ordinated Research Project on Floriculture at NARP, Ganeshkhind. Experimental materials consisted of 15 genotypes of single type tuberose obtained from AICRP on Floriculture.Seedling selection from hybrid progenies of different crosses identifiedeight new promising single type tuberose genotypes. The experiment was laid out in randomized block design with three replications. The land was ploughed to a medium depth. FYM was spread evenly@25 tonnes per hectare and recommended fertilizer dose 200:150:200 Kg NPK per hectare was incorporated. $100 \mathrm{Kg}$ Nitrogen was given as basal dose and two split doses $50 \mathrm{~kg}$ each at 60 days and 90 days respectively was spread after planting of bulbs. Flat beds of $1.8 \times 1.5 \mathrm{~m}$ plot size were laid and medium sizedbulbsof $2-2.5 \mathrm{~cm}$ diameter were planted at a spacing of $30 \times 30 \mathrm{~cm}$ which accommodated 30 bulbs per plot. Standard cultural practices were followed throughout experimentation. The data were recorded on three selected plants from each treatment and replication for vegetative, floral, bulb and bulb-lets characters.

\section{RESULTS AND DISCUSSION}

\section{Vegetative characters}

The mean performance of cultivars for vegetative growth characters (Table 1) reflected the variations among the cultivars. The earliest spike emergence was observed in cv. Arka Nirantara (60.89 days) but the genotype GK-T-C-4 required maximum days for spike emergence (67.89 days). Significantly highest plant height was recorded in cv. Variegated (138.64 $\mathrm{cm}$ ) and less in hybrid Phule Rajani X Arka Suvasini $(61.76 \mathrm{~cm})$ compared to other genotypes. This is in accordance with the results of Ranchana et al. (2013).More number of leaves per plant were observed in genotype GK-T-C-2 (24.11) and less in cv. Local Single (17.00). Flower bud was initiated at $5.78^{\text {th }}$ node in hybrid Phule Rajani x Arka Suvasini while cv. ArkaPrajwal flower bud started at $12.84^{\text {th }}$ node which was noted to be the highest. The significantly longest spike was observed in cv. Variegated $(124.37 \mathrm{~cm})$ and shortest in hybrid Phule Rajani x Arka Suvasini $(56.52 \mathrm{~cm})$. Hybrid L1P4 recorded significantly maximum rachis length (39.78 $\mathrm{cm}$ ) amongst 15 genotypes under study. The variation

Table 1. Performance of different tuberose genotype on vegetative growth characters

\begin{tabular}{|c|c|c|c|c|c|c|c|}
\hline Treatment & $\begin{array}{c}\text { Days to } \\
\text { spike } \\
\text { emergence }\end{array}$ & $\begin{array}{c}\text { Plant } \\
\text { height } \\
(\mathrm{cm})\end{array}$ & $\begin{array}{c}\text { No. } \\
\text { of } \\
\text { leaves }\end{array}$ & $\begin{array}{c}\text { Node at } \\
\text { which } \\
\text { floret } \\
\text { started }\end{array}$ & $\begin{array}{l}\text { Spike } \\
\text { length } \\
(\mathrm{cm})\end{array}$ & $\begin{array}{l}\text { Rachis } \\
\text { length } \\
\text { (cm) }\end{array}$ & $\begin{array}{l}\text { No. } \\
\text { of florets } \\
\text { per } \\
\text { spike }\end{array}$ \\
\hline Local Single & 63.33 & 94.81 & 17.00 & 10.56 & 89.73 & 20.49 & 39.56 \\
\hline Arka Shringar & 65.78 & 78.86 & 18.78 & 9.89 & 72.81 & 30.28 & 52.01 \\
\hline Phule Rajani & 65.44 & 74.49 & 20.45 & 8.84 & 69.74 & 33.61 & 52.84 \\
\hline Hyderabad Single & 66.67 & 77.47 & 20.00 & 9.73 & 72.46 & 28.41 & 47.59 \\
\hline Arka Nirantara & 60.89 & 95.27 & 21.89 & 12.17 & 86.93 & 26.77 & 54.25 \\
\hline Arka Prajwal & 62.78 & 94.83 & 23.55 & 12.84 & 91.14 & 32.53 & 57.56 \\
\hline Variegated & 62.99 & 138.64 & 21.45 & 11.33 & 124.37 & 24.55 & 45.36 \\
\hline Variegated x Phule Rajani L9P7 & 65.11 & 71.33 & 19.34 & 10.22 & 64.93 & 25.14 & 57.28 \\
\hline Variegated x Phule Rajani L1P4 & 62.22 & 116.39 & 20.56 & 11.78 & 109.58 & 39.78 & 57.25 \\
\hline Variegated x Phule Rajani L9P2 & 66.22 & 84.51 & 17.45 & 9.45 & 80.56 & 24.75 & 34.53 \\
\hline Local Single x Arka Shringar GK-T-C-1 & 63.89 & 76.93 & 19.56 & 9.23 & 70.71 & 30.62 & 55.14 \\
\hline Local Single x Arka Shringar GK-T-C-2 & 65.89 & 84.63 & 24.11 & 10.89 & 79.22 & 25.67 & 49.45 \\
\hline Local Single x Arka Shringar GK-T-C-7 & 67.00 & 76.56 & 18.78 & 8.33 & 70.83 & 30.66 & 58.58 \\
\hline Phule Rajani x Arka Suvasini & 64.22 & 61.76 & 18.89 & 5.78 & 56.52 & 36.72 & 49.95 \\
\hline Local Single x Arka Shringar GK-T-C-4 & 67.89 & 74.57 & 17.67 & 9.45 & 68.29 & 27.82 & 50.92 \\
\hline $\mathrm{SE}(\mathrm{m}) \pm$ & 1.25 & 2.03 & 1.14 & 0.44 & 1.65 & 0.94 & 1.63 \\
\hline C.D. at $5 \%$ & 3.63 & 5.92 & 3.33 & 1.29 & 4.81 & 2.72 & 4.76 \\
\hline
\end{tabular}


among different vegetative characters are attributed due to the difference in their genetic makeup. The number of florets recorded to be highest in genotype GK-T-C-7 (58.58). However, less number of florets was recorded in genotype L9P2 (34.53). Number of florets is an important character, as single type flowers are mostly used as loose flower. The variation in florets per spike may be due to genetic variability, disparity in storage of food among different cultivars and prevailing environmental condition.

\section{Flowering characters}

Among the fifteen genotypes evaluated for their floral characters (Table 2), the minimum days required for opening of first floret was noted in cv. Arka Prajwal (78.55days) whereas, significantly maximum days was required in genotype L9P7 (85.76 days). Significantly maximum inter-nodal length was noted in genotype L1P4 $(7.25 \mathrm{~cm})$. Cultivar Arka Prajwal recorded significantly thick diameter of spike $(1.18$ $\mathrm{cm})$ while it was thin in genotype L9P2 $(0.75 \mathrm{~cm})$. The diameter of spike influences the spike strength and reserved food material in it. The existing environmental condition and genetic factors influence the variation in spike thickness among different genotypes under study. Patil et al. (2009) and Arya et al.(2006) also reported similar results in tuberose.

Cultivar Arka Prajwal recorded maximum floret length $(6.05 \mathrm{~cm})$ and significantly minimum length of floret was recorded in cv. Hyderabad Single $(4.89 \mathrm{~cm})$. The diameter of floret was noted significantly maximum in hybrid L9P7 $(6.34 \mathrm{~cm})$ and minimum was recorded

Table 2. Performance of different tuberose genotype on flowering characters

\begin{tabular}{|c|c|c|c|c|c|c|c|c|c|c|}
\hline Treatment & $\begin{array}{c}\text { Days } \\
\text { for } \\
\text { opening } \\
\text { of } 1^{\text {st }} \\
\text { floret }\end{array}$ & $\begin{array}{l}\text { Inter- } \\
\text { nodal } \\
\text { length } \\
(\mathrm{cm})\end{array}$ & $\begin{array}{l}\text { Diameter } \\
\text { of cut } \\
\text { spike } \\
\text { (cm) }\end{array}$ & $\begin{array}{c}\text { Length } \\
\text { of } \\
\text { floret } \\
\text { (cm) }\end{array}$ & $\begin{array}{c}\text { Diameter } \\
\text { of floret } \\
\text { (cm) }\end{array}$ & $\begin{array}{l}\text { Weight } \\
\text { of cut } \\
\text { spike } \\
\text { (g) }\end{array}$ & $\begin{array}{c}\text { Weight of } \\
\text { individual } \\
\text { floret }(g)\end{array}$ & $\begin{array}{l}\text { Vase } \\
\text { life } \\
\text { (days) }\end{array}$ & $\begin{array}{l}\text { Spike } \\
\text { per } \\
\text { clump }\end{array}$ & $\begin{array}{c}\text { Spike } \\
\text { per } \\
\text { hector }\end{array}$ \\
\hline Local Single & 79.22 & 4.60 & 0.88 & 5.29 & 4.45 & 64.90 & 1.47 & 9.50 & 7.88 & 390799 \\
\hline Arka Shringar & 80.77 & 4.18 & 0.86 & 4.90 & 5.05 & 88.24 & 1.79 & 10.17 & 9.87 & 489284 \\
\hline Phule Rajani & 81.33 & 4.73 & 0.91 & 5.12 & 5.64 & 96.16 & 1.97 & 11.50 & 9.71 & 481187 \\
\hline $\begin{array}{l}\text { Hyderabad } \\
\text { Single }\end{array}$ & 83.44 & 3.25 & 0.95 & 4.89 & 5.37 & 81.53 & 1.74 & 10.00 & 8.13 & 403027 \\
\hline Arka Nirantara & 79.66 & 4.50 & 1.11 & 5.76 & 5.79 & 91.69 & 2.59 & 10.00 & 8.11 & 402036 \\
\hline Arka Prajwal & 78.55 & 4.97 & 1.18 & 6.05 & 5.65 & 121.43 & 3.12 & 10.17 & 9.04 & 448304 \\
\hline Variegated & 82.99 & 4.68 & 0.87 & 5.34 & 5.18 & 94.41 & 1.49 & 9.00 & 6.85 & 339409 \\
\hline $\begin{array}{l}\text { Variegated X } \\
\text { Phule Rajani } \\
\text { L9P7 }\end{array}$ & 85.76 & 4.21 & 0.87 & 6.04 & 6.34 & 88.89 & 2.49 & 9.00 & 7.77 & 385346 \\
\hline $\begin{array}{l}\text { Variegated X } \\
\text { Phule Rajani } \\
\text { L1P4 }\end{array}$ & 83.33 & 7.25 & 0.85 & 5.92 & 5.67 & 105.08 & 1.80 & 11.00 & 10.14 & 502669 \\
\hline $\begin{array}{l}\text { Variegated X } \\
\text { Phule Rajani } \\
\text { L9P2 }\end{array}$ & 81.22 & 3.60 & 0.75 & 5.28 & 5.08 & 57.52 & 1.94 & 9.17 & 10.57 & 523985 \\
\hline $\begin{array}{l}\text { Local Single X } \\
\text { Arka Shringar } \\
\text { GK-T-C-1 }\end{array}$ & 82.88 & 4.66 & 0.81 & 5.95 & 5.11 & 67.10 & 2.32 & 8.50 & 8.93 & 442520 \\
\hline $\begin{array}{l}\text { Local Single X } \\
\text { Arka Shringar } \\
\text { GK-T-C-2 }\end{array}$ & 81.55 & 3.67 & 0.91 & 5.66 & 5.59 & 81.10 & 2.07 & 9.67 & 10.06 & 498538 \\
\hline $\begin{array}{l}\text { Local Single X } \\
\text { Arka Shringar } \\
\text { GK-T-C-7 }\end{array}$ & 83.33 & 4.17 & 0.83 & 5.52 & 5.45 & 78.56 & 2.35 & 8.83 & 8.35 & 413933 \\
\hline $\begin{array}{l}\text { Phule Rajani X } \\
\text { Arka Suvasini }\end{array}$ & 80.22 & 5.79 & 0.85 & 5.22 & 4.52 & 48.57 & 1.94 & 9.17 & 8.22 & 407324 \\
\hline $\begin{array}{l}\text { Local Single X } \\
\text { Shringar GK- } \\
\text { T-C-4 }\end{array}$ & 81.33 & 4.15 & 0.86 & 5.31 & 4.99 & 67.15 & 1.94 & 9.83 & 8.90 & 441033 \\
\hline $\mathrm{SE}(\mathrm{m}) \pm$ & 1.24 & 0.27 & 0.02 & 0.24 & 0.26 & 2.99 & 0.17 & 0.52 & 0.42 & \\
\hline C.D. at $5 \%$ & 3.61 & 0.77 & 0.05 & 0.69 & 0.76 & 8.70 & 0.49 & 1.52 & 1.22 & \\
\hline
\end{tabular}


in cv. Local Single $(4.45 \mathrm{~cm})$. This variation among length and diameter of floret may be due to difference in the genetic makeup of cultivars. Significantly heavier cut spike (121.43g) and maximum individual floret weight $(3.12 \mathrm{~g})$ were noted in cv. Arka Prajwal. The variation in weight of individual and cut spike among different genotype is due to genetic factors, length and thickness of floret and spike respectively. These results are in consonance with findings of Mahawer et al. (2013) in tuberose.The longest vase life duration was observed in cv. Phule Rajani (11.50 days) which was at par with genotype L1P4 (11.00 days) whereas, shortest vase life was observed in genotype GK-T-C-1 (8.50 days). The variation in vase life of cut spike may be due to different genetic makeup of each tuberose genotype with prevailing environmental condition, which finally affects physiological processes like cell turgidity, water uptake through xylem tissues, water loss through transpiration, respiration and breakdown of reserved food material. Maximum number of spikes per clump and hectare was recorded in genotype L9P2 i.e. 10.57 and 523985.55 respectively. However, minimum number of spikes per clump and hectare were observed in cv. Variegated i.e. 6.85 and 339409.12 respectively.

\section{Bulb and bulb-lets characters}

Total number of bulbs per clump (11.00) and per plot (329.90) was produced more in genotype L9P2. While, minimum bulbs per clump (7.01) and per plot (210.20) was recordedin cv. Variegated. Maximum number of bulb-lets per clump was recorded in hybrid

Table 3. Performance of different tuberose genotype on bulb and bulb-lets characters

\begin{tabular}{|c|c|c|c|c|c|c|c|c|}
\hline Treatment & $\begin{array}{l}\text { No. of } \\
\text { bulb per } \\
\text { clump }\end{array}$ & $\begin{array}{c}\text { No. of } \\
\text { bulb-lets } \\
\text { per clump }\end{array}$ & $\begin{array}{l}\text { Length } \\
\text { of bulbs } \\
\text { (cm) }\end{array}$ & $\begin{array}{l}\text { Diameter } \\
\text { of bulb } \\
\text { (cm) }\end{array}$ & $\begin{array}{c}\text { Weight of } \\
\text { individual } \\
\text { bulb (g) }\end{array}$ & $\begin{array}{l}\text { Weight of } \\
\text { bulb-lets } \\
\text { (g) }\end{array}$ & $\begin{array}{c}\text { Diameter } \\
\text { of bulb-lets } \\
(\mathrm{cm})\end{array}$ & $\begin{array}{c}\text { Total } \\
\text { bulbs per } \\
\text { plot }\end{array}$ \\
\hline Local Single & 8.33 & 17.11 & 6.54 & 2.64 & 23.51 & 7.11 & 1.47 & 249.90 \\
\hline Arka Shringar & 10.28 & 23.44 & 6.08 & 3.39 & 39.13 & 7.67 & 1.58 & 308.30 \\
\hline Phule Rajani & 9.78 & 25.89 & 6.21 & 2.95 & 35.06 & 7.77 & 1.76 & 293.30 \\
\hline Hyderabad Single & 9.10 & 22.33 & 5.97 & 2.98 & 31.46 & 7.63 & 1.62 & 273.10 \\
\hline Arka Nirantara & 8.55 & 13.45 & 7.08 & 3.72 & 59.91 & 9.16 & 1.68 & 256.40 \\
\hline Arka Prajwal & 9.30 & 12.50 & 7.55 & 3.56 & 56.90 & 9.43 & 1.75 & 279.00 \\
\hline Variegated & 7.01 & 21.21 & 6.18 & 3.47 & 40.24 & 5.40 & 1.41 & 210.20 \\
\hline $\begin{array}{l}\text { Variegated X } \\
\text { Phule Rajani L9P7 }\end{array}$ & 8.60 & 15.89 & 5.87 & 3.15 & 38.73 & 7.83 & 1.63 & 258.10 \\
\hline $\begin{array}{l}\text { Variegated X } \\
\text { Phule Rajani L1P4 }\end{array}$ & 10.78 & 18.67 & 8.09 & 3.76 & 52.21 & 9.28 & 1.85 & 323.50 \\
\hline $\begin{array}{l}\text { Variegated X } \\
\text { Phule Rajani L9P2 }\end{array}$ & 11.00 & 25.33 & 5.87 & 3.26 & 43.23 & 8.39 & 1.58 & 329.90 \\
\hline $\begin{array}{l}\text { Local Single X } \\
\text { Arka Shringar } \\
\text { GK-T-C-1 }\end{array}$ & 9.87 & 17.10 & 6.04 & 3.26 & 34.29 & 9.86 & 1.54 & 296.00 \\
\hline $\begin{array}{l}\text { Local Single X } \\
\text { Arka Shringar } \\
\text { GK-T-C-2 }\end{array}$ & 10.52 & 16.33 & 5.46 & 2.98 & 43.47 & 8.43 & 1.56 & 315.50 \\
\hline $\begin{array}{l}\text { Local Single X } \\
\text { Arka Shringar } \\
\text { GK-T-C-7 }\end{array}$ & 8.48 & 24.09 & 5.65 & 2.91 & 28.30 & 7.05 & 1.48 & 254.50 \\
\hline $\begin{array}{l}\text { Phule Rajani X } \\
\text { Arka Suvasini }\end{array}$ & 8.22 & 28.66 & 6.02 & 3.04 & 35.07 & 7.67 & 1.40 & 247.93 \\
\hline $\begin{array}{l}\text { Local Single X } \\
\text { Arka Shringar } \\
\text { GK-T-C-4 }\end{array}$ & 9.26 & 23.78 & 5.73 & 3.13 & 43.31 & 8.41 & 1.64 & 277.80 \\
\hline $\mathrm{SE}(\mathrm{m}) \pm$ & 0.49 & 1.63 & 0.22 & 0.12 & 1.89 & 0.36 & 0.06 & 14.45 \\
\hline C.D. at $5 \%$ & 1.41 & 4.75 & 0.66 & 0.35 & 5.50 & 1.05 & 0.19 & 42.07 \\
\hline
\end{tabular}


Phule Rajani x Arka Suvasini (28.66) whereas, minimum were observed in cv. Arka Prajwal (12.50). Genotype L1P4 exhibited maximum length of bulb $(8.09 \mathrm{~cm})$ while genotype GK-T-C-2 recorded minimum $(5.46 \mathrm{~cm})$. The variation in number of bulbs produced per clump might be due to genetic factor which is further modified by prevailing environmental condition and the results are in consonance with finding of Chaturvedi et al. (2014) and Mahawer et al. (2013) in tuberose.Hybrid L1P4 exhibited maximum diameter of bulb $(3.76 \mathrm{~cm})$ and bulb-lets
$(1.85 \mathrm{~cm})$ while minimum diameter of bulb was recorded by cv. Local Single $(2.64 \mathrm{~cm})$. However, heavier bulb was produced by cv. Arka Nirantara (59.91 g) while it was lighter in cv. Local Single (23.51 g). Genotype GK-T-C-1 recorded maximum weight of bulb-lets $(9.86 \mathrm{~g})$. The variation in bulb weight per plant among different genotype at bulb harvesting stage might be due to the distinguished varietal genetic makeup with more leaves to improve photosynthetic activity, source sink relationship to accumulate more carbohydrate and prevailing condition.

\section{REFERENCES}

Arya, J.K., Singh, P.V. and Satyaprakah. 2006. Effect of bulb size on flowering of tuberose (Polianthes tuberosa L.) cv. Single. Prog. Agric. 6(2): 211-212.

Chaturvedi, A., Mishra, T.S., Kumar, N. and Singh, S.S. 2014. Screening of different cultivars of tuberose (Polianthes tuberosa L.) under agro climatic condition of Allahabad. Progressive Horticulture. 46(1): 146-148.

Mahawer, L.N., Bairwa, H.L. and Shukla, A.K. 2013. Field performance of tuberose cultivar for growth, floral and economic characters under sub-humid southern plains and Aravalli hills of Rajasthan. Indian J. Hort. 70(3): 411-416.
Patil, V.S., Munikrishanppa, P.M. and Shantappa, T. 2009.Performance of growth and yield of different genotypes of tuberose under transitional tract of north Karnataka.J. Ecobiol., 24: 327-33.

Ranchana, P., Kannan, M. and Jawaharlal, M. 2013. The assessment of genetic parameters: yield, quality traits and performance of single type genotypes of tuberose (Polianthes tuberosa L.). Adv. Crop Sci. Tech., 1(3): 111.

Singh, A.K. 2006. Flower Crops Cultivation and Management. Tuberose, pp: 357-370.

Yadav, L.P. and Maity, R.G. 1989. Tuberose. In: Commercial flowers (Eds) Bose, T.K. and L.P. Yadav. P. Vedams Books Pvt. Limited, New India. pp. 519-544.

(Received on 07.11.2019 and accepted on 09.07.2020) 